\title{
IDEOLOGÍA Y POLÍTICA Docentes y estudiantes en el contexto de la crisis liberal argentina El caso de la Universidad de Córdoba (1930-1943)
}

\author{
Dra. María Cristina Vera de Flachs ${ }^{1}$ \\ Universidad de Córdoba- Argentina \\ Grupo de Investigación HISULA-SHELA \\ vera@onenet.com.ar \\ Dr. Antonio Sillau Pérez ${ }^{2}$ \\ Universidad de Córdoba-Argentina \\ ansiper@hotmail.com
}

Recepción: 30/05/2008

Evaluación: 23/01/2009

Aceptación: 16/03/2009

Artículo de Reflexión

\section{RESUMEN}

Los investigadores preocupados por la historia de las universidades, por lo general, analizan el andar de esas instituciones como ajenas a la política y piensan que sus conflictos internos están lejos de ellas. Compartiendo criterios de otros estudiosos pensamos lo contrario, por tal razón en este artículo intentaremos demostrar como la política, el poder y las ideas se entrecruzan en una puja política-ideológica en un período de la historia de la Universidad Nacional de Córdoba que va desde 1930 a 1943 . Esa etapa de transición, que atestigua un proceso de profundización de la crisis multidimensional del proyecto liberal de la Argentina moderna, registra sus orígenes en el ámbito político a partir del golpe militar del 6 de septiembre de 1930 que derrumbó el régimen democrático del radical Hipólito Yrigoyen, y concluye con otra revolución,

\footnotetext{
1 Doctora en Historia, Licenciada en Historia por la Facultad de Filosofia y Humanidades, Profesora Titular de Historia Social Contemporánea. Facultad de Derecho y Ciencias Sociales. Universidad Nacional de Córdoba, Investigadora Principal del Consejo Nacional de Investigaciones Científicas y Tecnológicas. [CONICET]. Integrante del grupo de investigación Historia y Prospectiva de la Universidad Latinoamericana HISULA.

2 Magíster en Ciencia Política. Universidad Internacional de Andalucía, España, Licenciado en Historia. Universidad Nacional de Córdoba, Actualmente Auxiliar Docente de Segunda de la Cátedra de Historia Social Contemporánea, Escuela de Ciencias de la Información, Universidad Nacional de Córdoba.
} 
la del 4 de junio de 1943, que abriría nuevas esperanzas para los nacionalistas que no tardaron en comprobar que sus expectativas no iban a efectivizarse en tanto el régimen de "nueva cristiandad" o el "totalitarismo cristiano" no llegaría a cristalizar; aunque de cualquier modo, la "vieja Argentina" y su legado histórico de los años ochenta del siglo XIX tocaba su fin.

Los enfrentamientos vividos en la Universidad entre los grupos nacionalistas y los reformistas no estuvieron exentos de reflejar el complejo panorama político y el entrecruzamiento ideológico que aparecía en la dialéctica del juego político a escala nacional e internacional. A tales efectos, y en vinculación a esas transformaciones político-ideológicas se detallan las características de la politización en los claustros docente y estudiantil, reconociendo su repercusión en la praxis y devenir de la política universitaria.

Palabras Claves: Universidad, Reformistas, Nacionalistas, Ideología

\title{
IDEOLOGY AND POLITICS PROFESSORS AND STUDENTS IN THE CONTEXT OF THE ARGENTINE LIBERAL CRISIS. THE CASE OF THE UNIVERSIDAD DE CÓRDOBA (1930-1943)
}

\author{
Dra. María Cristina Vera de Flachs \\ Universidad de Córdoba-Argentina \\ HISULA-SHELA Reseach Group \\ vera@onenet.com.ar \\ Dr. Antonio Sillau Pérez \\ Universidad de Córdoba-Argentina \\ ansiper@hotmail.com
}

\begin{abstract}
Worried about the universities history, investigators generally analyze the activities of these institutions as if these were free from politics and think that their internal conflicts are far from them. Sharing other erudites' criteria, we disagree with that analysis. For that reason, this article intends to demonstrate how politics and ideas interweave in a politicalideological struggle in a period of the history of Universidad Nacional de Córdoba that went from 1930 to 1943. This transition stage, which testifies a deepening process of the multidimensional crisis of the liberal project of modern Argentina, registers its origins in the political scope by beginning with the military coup of September 6 of 1930 that overthrew the democratic regime of the radical Hipólito Yrigoyen and concluded with
\end{abstract}


another "revolution", the one of June 4 of 1943. This would open new hopes for the nationalists, who would soon realize that their expectations were not going to come true while the regime of "nueva cristiandad" or "Christian Totalitarianism" would not get crystallized. Any way the "old Argentina" and its historical bequest of the 80's would come to its end. The confrontations lived in the university between the nationalistic and reformist groups were not exempt of reflecting the complex political panorama and the ideological interweaving that appeared in the dialectics of the political game at national and international scale. As a consequence, in this regard, and related to these politicoideological transformations, both professors' and students' politization are detailed, recognizing their repercussion in both praxis and evolution of the university policy.

Key Words: University of Córdoba, Nationalists, Political and Ideological Fights.

\section{INTRODUCCIÓN}

Los investigadores dedicados a la historia de las universidades, por lo general, analizan el andar de esas instituciones como ajenas a la política y piensan que los conflictos internos están lejos de ella. Compartiendo criterios de otros estudiosos pensamos lo contrario, habida cuenta que en las altas casas de altos estudios se expresan diferentes visiones políticas e ideológicas sobre la institución y la sociedad. Por tal razón, en este artículo intentaremos demostrar como en la "Universidad Nacional de Córdoba la política y las ideas de la época se entrecruzan permanentemente en las pujas que enfrentaron a los dos sectores predominantes: nacionalistas y reformistas en el período que va de 1930 a 1943."3

Para situarnos en el tiempo haremos una breve reseña de lo ocurrido en el país en el período que se conoce como "década infame". Esta etapa de transición, que atestigua un proceso de profundización de la crisis multidimensional del proyecto liberal de la Argentina moderna, registra sus orígenes en el ámbito político con el golpe militar del 6 de septiembre de 1930, comandado por el general José F. Uriburu, que derrumbó el régimen democrático del radical Hipólito Yrigoyen. Como consecuencia de dicho proceso las provincias fueron intervenidas. En Córdoba fue designado interventor un hombre fuertemente comprometido con la reforma del sistema político y el nacionalismo, corriente que tuvo múltiples expresiones en varias jurisdicciones y en particular en ésta: el Dr. Carlos Ibarguren. Esto explica porqué a su arribo a la provincia éste no dudó en tomar contacto con un núcleo de intelectuales de esa extracción que actuaban en la Universidad y en el Colegio Monserrat en el período de estudio.

Desde el punto de vista ideológico ese lapso se caracteriza por la existencia de grupos que respondían a distintas concepciones "políticas: el socialismo, el liberalismo, el radicalismo y el nacionalismo, este último con perceptibles divergencias que genéricamente podrían ubicar a sus integrantes entre católicos, maurrasianos, filofascistas

3 ORDORIKA, Imanol. (2006): La disputa por el campus, poder, política y autonomía en la UNAM. México. UNAM. 
y populistas." Asimismo el período coincide con el fuerte impacto de la crisis económica mundial de 1930 en la economía nacional, lo que obligó a tomar medidas para enfrentarla. Basándose en las teorías vigentes, el Estado reguló precios y la producción a través de las Juntas Reguladoras, centralizó los sistemas impositivo y financiero, ejecutó obras públicas que permitieran paliar el problema del desempleo y fomentó la actividad industrial.

Por otra parte, la "cuestión social" era un tema pendiente y bajo un nuevo enfoque que privilegiaba las condiciones laborales y de vida de las clases trabajadoras, ganaba espacio entre los sectores eclesiástico, militar, político e intelectualidad nacionalista que pensaban que existía un problema de justicia social que debía ser abordado como tal, apelando a la activa intervención estatal.

Pero también esos años se caracterizan por la crisis de legitimidad de un sistema político dominado por prácticas electorales fraudulentas, implementadas por el aparato de la "Concordancia", y sostenido por el respaldo militar y por las continuas intervenciones federales a las provincias, con el fin de desarmar los gobiernos contrarios al "régimen". El escenario se complicó con la detonación de dos problemas internacionales: la Guerra Civil Española y la Segunda Guerra Mundial. La primera obligó a muchos españoles republicanos a emigrar, entre ellos a científicos y académicos los que encontraron en Argentina la posibilidad de insertarse en las universidades. La segunda, dividió la opinión pública entre aliadófilos y los defensores de las potencias del Eje, lo que se explica en un país donde las colectividades y los intereses económicos y culturales europeos tenían gran peso. Además, los efectos de la misma sobre la economía nacional ampliaron los fundamentos de la crítica a su carácter periférico y dependiente, fortaleciendo las bases de un nacionalismo económico que defendía la industrialización del país y la nacionalización de sectores claves de su economía bajo control de bancos y empresas extranjeras. No obstante, el aislamiento de los años de la guerra, coadyuvó a que se dieran algunos resultados positivos en la actividad industrial: se intensificó la producción y se movilizó la economía 5 .

\section{El Contexto Político-Ideológico en la Universidad a Comienzos de la Década del Treinta}

La Universidad de Córdoba nacida a comienzos del siglo XVII, recibió permanentemente en sus aulas estudiantes provenientes de diversas regiones. Para 1930 la misma concitaba la atención de los jóvenes provenientes de las provincias del noroeste, de Cuyo y de varios países latinoamericanos donde la Reforma de 1918 había tenido

\footnotetext{
4 Los autores que se ocuparon del tema encontraron dificultades para definirlo. El término nacionalista puede estar denominando a un grupo político, a una línea ideológica o a un movimiento cultural equiparable a otras grandes corrientes de pensamiento, como el iluminismo, o el romanticismo.

5 ACADEMIA NACIONAL DE LA HISTORIA. (2001): Nueva Historia de la Nación Argentina. Buenos Aires. Planeta. Tomo VII La Argentina del siglo XX.
} 
injerencia ${ }^{6}$. Por eso no debe extrañarnos que, desde entonces en adelante, la universidad viviera en constante clima de exaltación ideológica, alternándose períodos de reforma y contrarreforma como así también que sus distintos estamentos adoptaran distintas posiciones respecto a la situación política que se inicia en 1930.

Los nacionalistas, enemigos de la Reforma de 1918 a la que veían contraria al catolicismo y atada al comunismo y a otras ideologías foráneas, pensaron que había llegado su hora y que, al fin, detentarían el gobierno universitario. Entre las actividades desplegadas planearon la constitución de organismos defensivos de emergencia, entre las que se contaban la Acción Nacional de Estudiantes de Derecho, la Corporación Nacional de Medicina y la Federación Universitaria Nacionalista Argentina, los que unieron su accionar a otras agrupaciones nacionalistas a las que haremos referencia luego.

Por su parte, el grupo reformista, si bien no tuvo un protagonismo activo, de inmediato repudió el nuevo régimen político y, poco después, denunció la firma de un pacto entre el jefe de policía local, Aníbal Montes y un grupo de profesores universitarios y de militantes nacionalistas por el que se perseguiría todo aquello que oliera a Reforma o comunismo. "Obviamente esta acusación causó gran revuelo no sólo en la universidad sino en el resto de la sociedad." En respuesta, los jóvenes reorganizaron sus centros en las distintas facultades y en una asamblea impugnaron el convenio mencionado.

Entretanto, la Universidad había llamado a elecciones para elegir rector, resultando electo, tras una puja reñida, José Benjamín Barros, hombre proveniente de la Facultad de Ciencias Exactas, Físicas y Naturales y de raigambre reformista; de allí que en los escasos diez meses que estuvo al frente de la misma, los jóvenes reformistas se vieron contenidos. Sin embargo, al promediar el año 1931, la universidad vio como los días de calma llegaban a su fin. Nadie hablaba de enseñanza gratuita, ni de docencia libre, ni de programas integrales, y, por el contrario, la lucha entre los diversos sectores se agudizó. Los católicos se movilizaron y realizaron actos en contra de los reformistas; quienes, a su vez, reaccionaron y organizaron distintas actividades. Por ejemplo un grupo más politizado constituyó en la Facultad de Derecho, el 24 de mayo, el "Centro Reformista de Izquierda, auspiciado por Alfredo L. Palacios cuya meta era analizar con imparcialidad el caos en que se debatía la organización universitaria e intentar extender el movimiento a toda América." ${ }^{8}$ Otros, se pronunciaron contra el decano

\footnotetext{
6 La Reforma de 1918 se extendió por otros países latinoamericanos. Perú, México, Colombia, Cuba sintieron su influjo. La bibliografía sobre el tema es extensa y de dispar valor. Véase a MARSISKE, Renate. (1989): Movimientos estudiantiles en América Latina. Argentina, Perú, Cuba y México, 1918-1929, México, Centro de Estudios sobre la Universidad. BIAGINI Hugo. (2000): La Reforma Universitaria: antecedentes y consecuentes. Buenos Aires. Leviatán; DEL MAZO Gabriel. (1968): La Reforma Universitaria, tomo 3, Lima, Universidad Nacional Mayor de San Marcos.

7 La Voz del Interior. Córdoba. Argentina, 8 de octubre de 1930.

8 Alfredo Palacios, 1880-1965. Político de ideología socialista fue a partir de 1904 varias veces diputado y senador entre (1934-1942). En 1915 se enfrentó a la ortodoxa del Partido Socialista, que abandonó, renunciando también a su banca de diputado. Adhirió fervientemente a la Reforma de 1918. Opositor al peronismo, abandonó Argentina, a donde regresó a la caída de Perón. Volvió a ser senador entre 1961-1962.
} 
electo de Medicina, Dr. Juan M. Albarenque, al que llegaron a agredir tirándole huesos molidos sobre su vestimenta. "Hecho que fue repudiado de inmediato por la Federación Universitaria quien señaló que no propiciaba ningún acto de violencia."

Todo concluyó el 19 de junio de ese año, cuando después de tres días de desórdenes la fuerza policial invocando órdenes superiores ingresó a la Universidad. "En respuesta al atropello el ingeniero Barros presentó su renuncia indeclinable al rectorado aduciendo que, con esa medida, se había afectado la autonomía universitaria y su dignidad"10. Fue reemplazado por otro ingeniero de extracción más conservadora: Eduardo Deheza. Poco después, el 31 de agosto, una bomba destruyó la sede del diario católico, Los Principios. Obviamente este acontecimiento repercutió en la Universidad y quebró a los dos grandes partidos políticos provinciales: el demócrata y el radical que tenían entre sus filas a muchos adherentes católicos que pertenecían a los distintos claustros y que sintieron terror ante este hecho.

Cuando se convocó a elecciones presidenciales en 1932 los reformistas apoyaron políticamente a los candidatos de la Alianza Demócrata Progresista-Socialista y la candidatura presidencial de Lisandro de la Torre y Nicolás Repetto. El triunfo del general Agustín P. Justo, que comandaría los destinos de la Nación entre 1932 y 1938, hizo ver a los jóvenes que éste sería una continuación del gobierno del general Uriburu, por lo que pronto se percataron que iba a ser necesario utilizar todos los medios que disponía la democracia, aun cuando la reconocieran fraudulenta, para lanzarse a la lucha enarbolando nuevamente la bandera de la Reforma de 1918.

Este marco político de confrontaciones se mantuvo durante toda la década, y hubo momentos de gran tensión y conflictos en el que se vieron envueltos no sólo los estudiantes sino las autoridades de la casa de altos estudios, sus profesores, otras instituciones de peso en la sociedad local y los partidos políticos.

\section{La Huelga del '32}

Las secuelas del proceso político ideológico que vivía el país no tardaron en cimbrar a la universidad. La ocasión se presentó el 9 de abril de 1932 cuando el rector informó que se produjeron desórdenes en los actos de inauguración del ciclo lectivo por los "mismos elementos que dentro y fuera de la universidad estaban empeñados en agitar el ambiente estudiantil", en consecuencia el CS resolvió expulsar a un grupo de jóvenes. ${ }^{11}$ Poco después dos profesores y consejeros de la Facultad de Medicina, Doctores Gregorio Bermann y Jorge Orgaz, reformistas y de extracción socialistas, se pronunciaron en nota presentada al Consejo Directivo de la Facultad de Medicina- en contra de las autoridades universitarias a las que le reprocharon que habían estado al frente de la universidad durante el gobierno militar que había sometido a toda clase de

\footnotetext{
9 La Voz del Interior. Córdoba. Argentina, 18 de junio de 1931.

10 La Voz del Interior. Córdoba. Argentina, 14 de junio de 1931.

11 Eran éstos Mario Quinteros, Mateo y Antonio Seguí, Cataldo Mocciaro, Adolfo Imaz y Regino Casco.
} 
vejaciones a los reformistas. "La respuesta fue la separación de ambos de sus cátedras y la exoneración de los estudiantes que apoyaban esa postura." 12 Inmediatamente se generalizaron las adhesiones de los diferentes centros de estudiantes de todas las facultades y se constituyó un comité de lucha.

Entretanto, en mayo, la Federación Universitaria de Córdoba [FUC] decretó una huelga que fue conducida por dos estudiantes de Medicina, Marcos Meeroff y Tomás Bordones, y que contó con el apoyo solidario de los centros de las universidades de $\mathrm{La}$ Plata y Rosario, de las bancadas parlamentarias de los partidos Socialistas, Demócrata Progresista, de sectores del Radicalismo y de la prensa local adicta que los apoyó sin restricciones. Lo importante de este conflicto es que nuevamente estuvieron presentes los postulados reformistas del '18, es decir, se insistió en una Universidad progresista, de base científica y humanista, con concursos legítimos, ingreso pleno y discriminado, remuneración digna al cuerpo docente y la presentación de un proyecto de ley universitaria para ser presentado al Parlamento Nacional, tema este de gran preocupación desde hacía tiempo.

Trascendiendo la vida universitaria los jóvenes propugnaban la plena legalidad democrática y el reconocimiento de los derechos sociales de la clase obrera, la defensa de la riqueza nacional incluyendo el subsuelo, una consiguiente política anti-imperialista y colaboración con los países latinoamericanos, cuestiones éstas de vigencia entre la intelectualidad y los políticos de entonces que veían con preocupación la posibilidad de privatizar las fuentes hidroeléctricas de la provincia.

En plena huelga, el 15 de junio, "los reformistas conmemoraron otro aniversario de la Reforma, oportunidad que en un encendido discurso el estudiante Bordones señaló que la lucha no era sólo contra las autoridades universitarias sino contra el espíritu regresivo que desvirtuaba el rol que debía cumplir la Universidad.”13

En agosto, las cosas se complicaron habida cuenta que los estudiantes declararon caducidad de las autoridades de la Facultad de Medicina haciéndose cargo simbólicamente de la mesa directiva de la FUC quien reincorporó al Dr. Orgaz. La Gaceta Universitaria, en un Boletín extraordinario editado esos días, señaló en un artículo titulado Hablamos nosotros que habían tomado la universidad para que no cayera "en las inmundas manos de la reacción...."

y agregó lo hemos hecho además para precipitar el choque definitivo", lo que demuestra que el conflicto iba más allá y, a la vez, tomaba dimensión nacional en momentos que en Buenos Aires los jóvenes se reunían en el Segundo Congreso Nacional Universitario. Un grupo universitario más combativo,

\footnotetext{
12 A.G.U.C, Actas del Consejo Superior, fs 255, 274 a 282. Poco antes los estudiantes habían hecho algunas escaramuzas al solicitar otra vez la rebaja de los aranceles y la restitución del Estatuto de 1929.

13 Entrevista realizada por la Dra. Vera de Flachs a Leticia Aguirre, esposa de Tomás Bordones en el año 2001.
} 
Insurrexit, impulsaba acciones callejeras y la politización de la huelga, a la vez que atacaba a la FUC por considerar que no era lo suficientemente combativa. ${ }^{14}$

Entretanto se confirmaba a Sofanor Novillo Corvalán como rector. La FUC 1o enfrentó y desconoció la designación del Dr. Juan M. Albarenque como decano de Medicina pero la huelga se fue debilitando a fines de ese año y, a comienzos del siguiente los estudiantes, que habían perdido el año lectivo, se pronunciaron en una asamblea mayoritariamente en contra del paro por considerarlo estéril a esa altura.

\section{El Instituto Santo Tomás de Aquino y la Idea de una "Nación Católica" como Proyecto Político Definido}

La Iglesia y cierta clase política provincial, tuvo en claro desde temprano que los movimientos sociales y estudiantiles contrarios a ellos se podían combatir por la fuerza pero que era más útil instituir agrupaciones católicas u otras que sirviesen para apoyarlos. Así los estudiantes en un intento por oponerse a la FUC, organizaron la Federación Católica Universitaria [FCU], sobre la base de los centros juveniles preexistentes que hemos mencionado adoptando el lema: "Dios y Patria"15.

Por otro lado, cabe destacar que como consecuencia de los hechos ocurridos después de la Reforma de 1918 en la década del veinte un grupo de intelectuales católicos, de orientación tomista y nacionalista entre los que se contaban Nimio de Anquín, Rodolfo Martínez Espinosa, José María Martínez Carreras, Clemente Villada Achával, Ascencio Viramonte Oliva, comenzó a reunirse periódicamente en casa del Dr. Luís Martínez Villada. Pronto se percataron de la necesidad de fundar un Instituto de estudios superiores bajo la advocación filosófica y teológica de Santo Tomás de Aquino $^{16}$. Ese fue el origen del Instituto del mismo nombre que si bien no llegó a dictar

\footnotetext{
14 Insurrexit había nacido el año anterior en Buenos Aires con el fin de aplicar en la universidad una línea de ultra izquierda. Entre sus fundadores se encontraba Ernesto Sábato, Héctor P. Agosti, Carlos Moglia y otros intelectuales jóvenes. En Córdoba los militantes más destacados fueron: Jorge J. Cabodi, Juan Zanetti, Mateo y Antonio Seguí, Vicente y Cataldo Mocciaro, Carlos Bordi, etc. VERA DE FLACHS, María Cristina. (2005): Reformas y Contrarreformas en la Universidad de Córdoba, 1918-1936 en Movimientos Universitarios. América Latina siglo $X X$.VARGAS HERNANDEZ Olmedo. Colombia. Editorial Jotamar, pp.117-140.

15 Los Principios, Córdoba, Argentina, 25 de junio de 1932. El lema, adoptado en sus Estatutos, se debió a que el Centro se constituyó sobre la base de la doctrina católica, apostólica y romana y en defensa de la Patria. Cabe aclarar que en sus considerandos se dejaron abiertas las puertas para que los estudiantes de otras agrupaciones pudiesen entrar siempre que no pertenecieran a partidos antirreligiosos o antinacionalistas. A pesar de la amplitud en las disposiciones previstas el Centro no tuvo el arraigo esperado en las bases universitarias.

16 Nimio de Anquín nació en Córdoba el 12 de agosto de 1896 en el seno de una familia acomodada. Estudió en la Universidad y, en 1927 junto con Carlos Astrada fue becado para realizar estudios en Europa. Allí conoció a Ernesto Cassirer. Como lo reconocieron algunos de sus discípulos era un profesor de "otra dimensión" con formación europea y gran dominio de los temas que enseñaba. Dictaba sus clases en español, alemán, latín y griego, por lo que varios alumnos comenzaron a estudiar dichos idiomas como materia extra-universitaria y confeccionaban una lista con las voces más usadas en las clases de Lógica. Comenzó enseñando
} 
cursos regulares se caracterizó porque sus miembros daban conferencias con el fin de atraer y vincular al centro a otros jóvenes. Así se fueron incorporando entre otros, Manuel Río, Francisco J. Vocos, Jaime García Vieyra, Roberto Peña, etc., jóvenes que luego tuvieron trayectoria como docentes universitarios. Lectores incansables, con un pensamiento auténticamente tradicionalista pugnaban por restaurar la vida espiritual en tiempos donde el mundo estaba convulsionado, además de tener en claro la necesidad de efectuar reformas políticas, en las que incluían el deseo de una universidad católica como "reino de la razón y de la inteligencia".

A fines de la década del treinta y como consecuencia de los episodios que narraremos a continuación, obra del accionar político de Anquin, el grupo se fue dispersando y concluyó con la disolución del Instituto.

\section{Politeia: Un proyecto de Constitución Política}

No obstante, antes de que ello ocurriera, esta intelectualidad explicitaba sus pretensiones en torno a crear un "nuevo orden", que Nimio de Anquín definía a manera antitética en base a tres términos: "es antiliberal, también antirrenacentista y antiburgués." ${ }^{17}$ El proyecto de constitución política fue obra de Martínez Espinosa, quien lo presento a través de su "Politeia." 18 En este documento se reflejaban, en forma genérica, las concepciones que animaban a los integrantes del Instituto Santo Tomás de Aquino, en tanto sintetizaba la idea de una "nación católica" como "proyecto político definido" 19 .

En este sentido, apuntaba a una propuesta de transformación político-institucional en relación al ordenamiento constitucional de 1853, y que aparece en la pretensión de estructurar un poder eclesiástico-católico legitimante del orden político-social, fundado en el autoritarismo y en el ordenamiento jerárquico, y en la organización social corporativa. La combinación de estos elementos nos muestra a las claras la asunción de una perspectiva política marcadamente antimoderna, cuyas concepciones medievalistas

\footnotetext{
esta materia en el Monserrat en 1930 y al igual que en las clases dictada por el italiano Rodolfo Mondolfo nadie se movía. Después de un destierro temporario regresó a Córdoba y en 1945 tuvo a su cargo la misma cátedra en la Facultad de Filosofia y Humanidades. CATURELLI, Alberto. (1993): Historia de la Filosofia en Córdoba El siglo XX. Córdoba, p.308.

17 ANQUIN, Nimio de. (1941): "Liberalismo subrepticio y libertad cristiana", en Nueva Política. No 10. Buenos Aires, p. 10.

18 Este punto se redactó en base a los datos de la tesis de Maestría en Ciencia Política de Antonio SILLAU PEREZ titulada Caracterización del pensamiento nacionalista en Córdoba en el período de entreguerras. Una propuesta católica desde el interior (1919-1943). Universidad Internacional de Andalucía. España, 2008, inédita. MARTÍNEZ ESPINOSA, Rodolfo. (1933): Politeia. Inédito. Sobre este documento existen tres redacciones del año 1933 y de 1937.

19 No en vano, tampoco, Martínez Espinosa, años después, había afirmado que cuando redactó Politeia, el Instituto Santo Tomás la aprobó haciéndola suya. Cfr. Una curva histórica, Conferencia leída en los Cursos de Cultura Católica, Buenos Aires, 25 de noviembre de 1948, Inédito.
} 
no nos alejarían de una idealizada cristiandad medieval; temática trillada entre los miembros del Instituto que veían, por ejemplo, a N. Berdiaeff como uno de sus teóricos preferidos.

El autor destaca, en las diversas redacciones de Politeia, el carácter necesariamente vinculante de una futura constitución con lo que define como "la naturaleza o sea al devenir verdadero de la nación para la que es dictada... "(y) Guay del pueblo que no acierta con el régimen apropiado a su idiosincrasia." ${ }^{20}$ Esta precisión encontraba su fundamento último en el carácter confesional pleno que debería asumir la nación, reconociendo en la Iglesia a la "verdadera alma de la nación". Sustentado en el carácter eminentemente confesional de la nacionalidad, el documento refería diversos aspectos que definían y motorizaban un proyecto político alternativo en relación al vigente de 1853. Esto es visible cuando se aborda la composición y relación entre los poderes del Estado, nos referimos al legislativo y ejecutivo, pues el judicial no fue tratado. Aristocratismo y autoritarismo marcan la pauta de una marcada supremacía política del ejecutivo: a cargo de un "presidente", que es "quien gobierna realmente la Nación" acompañado en su acción, en lo administrativo por ministerios, pero asesorado en materia de decisiones por "un Consejo de notables (elemento aristocrático del gobierno), constituido por ciudadanos que se hayan distinguido por sus servicios eminentes al país". En tanto, el poder legislativo, compuesto por una Asamblea General que incluía a representantes del gobierno, del clero y de las corporaciones, quedaba constreñido a una actuación temporal cuando fuesen convocados por el gobierno "cuando este vea la necesidad de nuevas leyes, para deliberar sobre su conveniencia y sanción" 22 .

Otro aspecto central que aborda Politeia es el relativo al corporativismo, al que considera necesario reformarlo aunque conservando, lo que el autor concibe como el "tipo moral" de la Edad Media: la corporación aparece en el documento como una instancia que neutraliza los elementos conflictivos relativos a la competencia económica, a la lucha de clases y a las contraposiciones ideológicas en el plano político. A las corporaciones, atribuye todo lo relativo a la producción y a las cuestiones relacionadas

${ }^{20}$ SILLAU PEREZ, Antonio. (1937): Caracterización del pensamiento nacionalista en Córdoba en el periodo de entreguerras. Una propuesta católica desde el interior (19191943). Universidad Internacional de Andalucía. España.

21 El mismo, informaba sobre las ccondiciones de tal función: durabilidad del cargo, independencia y primacía real respecto de los otros poderes en cuanto al pleno poder de decisión que inviste".

22 "La inocuidad y peligros propios de un poder legislativo en funciones permanentes son la enseñanza de la historia política moderna. En países republicano democráticos las Cámaras han controlado de tal manera al Ejecutivo que toda obra de gobierno llegó a ser imposible. Por lo demás, la tendencia antiparlamentaria es tan universal hoy que la exclusión de estos cuerpos en su forma moderna no necesita ser comentada. La labor de este poder no puede ser otra que la expresión del "consensu populi" necesario para la aprobación de las leyes y debe, por consiguiente, circunscribirse a los momentos o tiempos de legislación. Pero para que realmente exista "consensu populi" la composición de los cuerpos legislativos tiene que ser muy distinta a la actual y exige la organización corporativa de la nación". (Politeia., Primera redacción 1933 y 1937). Por otra parte, en el apartado que corresponde a Las Provincias, el régimen federal existente en la constitución de 1853 se mantiene, pero ahora, "inspirado en los (nuevos) principios establecidos para la nación...”. 
con el trabajo, "siendo responsables de entre ambas ante el Estado, quien...se descarga en estos organismos de tales funciones". Por contraposición al estatismo fascista, Martínez Espinosa reafirma la concepción católica del corporativismo, destacando la aplicación del principio de subsidiariedad que remite a la encíclica Quadragesimo Anno de Pío XI: "la constitución de los grupos profesionales (las corporaciones) con definidas calidades sociales, jurídicas y económicas, porque debe aplicarse el principio de que es injusto y pernicioso encomendar al Estado aquello que puede ser resuelto por comunidades menores o inferiores" 23 .

En el documento se realiza además una serie de precisiones relativas a la actividad agrícola, industrial, control de capitales extranjeros y reformas sociales. En los primeros dos puntos, el sesgo del supuesto agrarista es innegable en tanto la Argentina es un país "naturalmente" agrícola ganadero y al otorgar a la industria un papel claramente conservador: "Debe propiciarse aquellas que tienden a llenar las necesidades del pueblo y para las cuales se encuentre la materia prima dentro del país" ${ }^{24}$. Por otra parte, de manera genérica, la idea de la "independencia económica" apuntaba a desmontar el predominio que ejercían los "bancos y empresas extranjeras en sectores claves de la economía, de ahí partía la exigencia de control a los capitales extranjeros o al "bárbaro imperialismo anglosajón" y hacia el dirigismo estatal" 25 . En lo referente a reformas sociales, repetía tópicos tratados reiteradamente desde el catolicismo social: "exclusión de la mujer y del niño de los trabajos de fábrica y de taller", "participación del obrero en las utilidades de la empresa", "defensa de la pequeña industria", "seguro social del obrero", etc.; aunque es necesario aclarar que el tratamiento de este conjunto de aspectos no ocupó más que un lugar secundario en los trabajos de la intelectualidad del Instituto, bajo el supuesto de que el abordaje y solución a los "males" del país pasaba fundamentalmente por el orden de las transformaciones político-institucionales y, por supuesto, en el establecimiento de un Estado confesional"26.

Un último punto, interesante de comentar sobre el documento, es que contiene un apartado relativo a la "cuestión étnica", donde destacan dos puntos de importancia en el debate de aquellos años: el de la inmigración y el de la minoría judía. Sobre el primer punto, se apunta básicamente a conservar el fomento a las corrientes de inmigración europea, aunque la precisión pasa por una inmigración compatible con los "valores nacionales", y que lógicamente, deben fundarse en el catolicismo en contraposición al "cosmopolitismo extranjerizante". Sobre la "cuestión judía" se habla de un "régimen especial", que desde luego implicaba, en el contexto antisemita de la Argentina de los años treinta, la pretensión de diferenciar a "judíos" de "cristianos", o más aún, de los

\footnotetext{
23 MARTÍNEZ ESPINOSA, Rodolfo. (1933): Politeia. Primera redacción de 1933 y redacción de 1937.

24 MARTÍNEZ ESPINOSA, Rodolfo. Op., cit. p. 100.

25 "Los capitales extranjeros invertidos en el país serán objeto de una legislación que los subordine, taxativa y plenamente al interés nacional. Un organismo directamente dependiente del gobierno y del que sólo podrán formar parte los argentinos nativos, fiscalizará las empresas, concesiones, etc., establecidas a base de dichos capitales".

${ }^{26}$ Op., cit. p. 100
} 
"argentinos", y a través de la "fiscalización de sus actividades" eliminar su influencia que, desde luego, se calificaba de negativa en la vida pública nacional”27. Por supuesto, este tipo de medidas, que se consideraban "aceptables" y no incompatibles con los principios cristianos; más bien, típicas de un antisemitismo tradicional, distaban del racismo biológico nacionalsocialista, condenado, por otra parte, en más de una oportunidad por los miembros del Instituto.

\section{La Europa Autoritaria y los Alcances de su Recepción Ideológica en la Intelectualidad del Instituto Santo Tomás de Aquino y en la Universidad}

A la altura de los acontecimientos descritos debemos preguntarnos cuáles fueron los alcances o límites de la influencia ideológica del fascismo italiano y del nacionalsocialismo alemán en Argentina y, en particular sobre la intelectualidad universitaria de Córdoba y del Instituto Santo Tomás.

Evidentemente el ascendiente del fascismo italiano, entre el clero y la militancia católica argentina fue un factor decisivo en su evolución ideológica a partir de 1932. Esto es fácil de corroborar en los estudios aparecidos en los últimos años, sin embargo debemos hacer notar que si bien ellos han mencionado lo ocurrido en Córdoba el tema no ha sido trabajado específicamente, lo que permitiría una comprensión real de la dimensión y alcance de esas ideas y su proyección en el movimiento político que hizo su aparición a mediados de la década del cuarenta. "Si logramos marcar con este artículo lo ocurrido en esta provincia, sin duda será nuestra contribución"28.

Para la intelectualidad del Instituto Santo Tomás y para algunos docentes universitarios, el ascenso de Mussolini encontraba justificación. Por ejemplo, Nimio de Anquín, había otorgado su aval a la reacción fascista en Italia frente al "comunismo

\footnotetext{
27 Durante los años treinta el antisemitismo ocupó un lugar relevante en el discurso de la ideología nacionalista argentina. Particularmente, desde el nacionalismo católico se consideraba la presencia de judíos en el país como un «riesgo» a la «nacionalidad» (o a su «carácter» católico latino). Este tipo de ideas comúnmente se combinaba con otras procedentes de un «complot» multifacético judío de guerra contra el cristianismo y de un mundo dominado por los judíos. Cf. BEN DROR, Graciela. (2003): Católicos, Nazis y Judíos. La Iglesia Argentina en los Tiempos del Tercer Reich, Colección Nuevas Miradas a la Argentina del Siglo XX. Director Raanan Rein, Universidad de Tel Aviv. Editorial Lumiere. Buenos Aires. ${ }^{28}$ Cfr. entre otros que se ocuparon del tema, ZANATTA, Loris. (1996): Del estado liberal a la nación católica a la nación católica. Iglesia y ejército en los orígenes del peronismo. 1930-1943. Universidad Nacional de Quilmes, p. 280; BUCHRUCKER, Cristián. (1987): Nacionalismo y peronismo. La Argentina en la crisis ideológica mundial (1927-1955. Buenos Aires Editorial. Sudamericana, p. 174. ZULETA ÁLVAREZ, Enrique. (1975): Introducción a Maurras. Nuevo Orden. Buenos Aires. (1975): El nacionalismo argentino. Buenos Aires. Editorial La Bastilla. "España y el nacionalismo argentino" en Cuadernos del Sur, No. 23-24, 1990-1991. "Los gobiernos de la Concordancia", en Academia Nacional de la Historia, Nueva Historia de la Nación Argentina., vol. VII, pp. 265-297. Los artículos aparecidos en Los Principios, periódico que amplió considerablemente su información sobre Italia en esos años muestran, por lo general, términos elogiosos el estatismo fascista.
} 
diabólico"; más aún, él llegó a expresar sus aspiraciones a lo que definía como un "fascismo teocéntrico" (o a lo que calificaba como la "cruzada santa,"29 el cual operaría como fundamento doctrinario de la Unión Nacional Fascista y del futuro advenimiento del "nuevo orden" en la Argentina. Para de Anquín, este "fascismo teocéntrico" era el que respondía a la "auténtica tradición hispánica" de la Argentina, tal "cual lo había declarado el Fascismo Argentino en Córdoba en 1934," 30 antes de constituirse en la base de la formación del Frente de Fuerzas Fascistas en 1935, agrupación que, en 1936, se denomina Unión Nacional Fascista.

Por su parte, Rodolfo Martínez Espinosa, ese mismo año, no dejaba de elogiar la figura de Mussolini, calificándola como la única que "ha procedido con mano maestra en todo este fin de época moderna "[...] liquidando la masonería y las demás sociedades secretas, cuyo juego conocía a fondo por su acción sobre el socialismo"31.

Luís Martínez Villada, mostrando las persistentes ambigüedades en el mundo católico frente al fascismo italiano, o incluso frente al nacionalsocialismo alemán pese a las reiteradas y enérgicas condenas por sus prácticas raciales y por su persecución a la Iglesia, comentaba en 1938, lo siguiente:

[...] sin ocultar ya los males, ya los peligros, ¿quién negará cuán admirable es el espectáculo del pueblo alemán, derrotado empobrecido, despojado, humillado, teniendo en medio de los dolores y confusión del vencimiento, que defenderse del comunismo y marchando con disciplina y vigor hacia la recuperación de su territorio ocupado y al restablecimiento de su antiguo poderío?; y a renglón seguido agregaba sobre Mussolini: que sólo la pasión ciega, el pavor democrático y el rencor masónico, pueden negar y combatir lo que hay de espléndido en la obra de Benito Mussolini ${ }^{32}$

Estas afirmaciones precedentes, no ocultaban el hecho que, desde 1936, en el seno del catolicismo argentino y específicamente desde Córdoba, comenzaban a disputarle al fascismo italiano espacios de protagonismo otras "alternativas", como el nazismo o el franquismo español (o el "fascismo teocéntrico" de Nimio de Anquín).

El impacto del ascenso del poderío nazi no sólo quedaba expresado en frases tan directas como la expuesta por Martínez Villada (que parecía, por otra parte, reproducir lo más vulgar de la propaganda nazi), sino en comentarios indirectos, aunque no menos sugestivos del mismo autor, al aludir al "más espantoso conflicto que está suspendido como terrible amenaza sobre el mundo," ${ }^{33}$ precisamente cuando el nazismo ya formado el Eje Berlín Roma comenzaba su aventura por Europa.

\footnotetext{
29 Este fascismo es el que se está gestando en España con sangre de mártires y al que nosotros pertenecemos al propiciar el reinado de Jesucristo". Crisol, 12 de septiembre de 1936.

30 Crisol, 7 de febrero de 1934.

31 Carta a Julio Irazusta, noviembre de 1936.

32 MARTÍNEZ VILLADA, Luís Guillermo. (1938): Democracia y orden politico. Córdoba, p. 17.

33 Ibídem. p. 18.
}

Rhela. Vol. 12. Año 2009, pp. $247-273$ 
En todo caso, este conjunto de afirmaciones previas, más allá de los contextos de ambigüedad de los que surgían, podían remitirnos a un tipo de respuesta si se trataba de hacerlo ante la duda de si los católicos debían colaborar con los movimientos de tipo fascista (producto de la controversia desatada por Jaques Maritain en oposición a César Pico, Julio Meinville, Gustavo Franceschi, etc.), la respuesta, en nuestro caso de estudio, no podía sino ser afirmativa: Mussolini, Hitler y Franco, aparecían bajo la mirada de esta intelectualidad católica como la encarnación de la única fuerza anticomunista dotada de eficacia. En última instancia, frente al "comunismo diabólico", no se escatimaban medios en todo lo que se propusiera eliminarlo.

Otros planteos que mostraban, posiblemente, más falta de sentido común que de conocimiento real de estos fenómenos, conducían a apreciaciones que consideraban una posible "restauración cristiana" de la mano del fascismo italiano o del nacionalsocialismo alemán. Pero más allá de estas apreciaciones previas, la contraposición con elementos claves en el área ideológica del fascismo italiano y del nacionalsocialismo alemán son visibles. Aspectos centrales relacionados al Estado, en el primer caso, y a la raza, en el segundo, nos arrojan resultados visiblemente contrastantes, en lo que consideraban, por supuesto, "tendencias anticristianas" ${ }^{34}$. Esto, por cierto, no encajaba en la visión u objetivo fijado en relación al proyecto político que debería marcar hacia el futuro, el advenimiento del "nuevo orden". En tal sentido, se puede observar que la aproximación al fascismo o al nacionalsocialismo fue más bien de tipo instrumental (o más bien, parcial), es decir que es perceptible, en uno y otro caso, en la utilización de elementos tales como el anticomunismo, la abolición del liberalismo y la democracia, el ataque al "espíritu burgués", y en la crítica antiimperialista y frente a la explotación capitalista hacia las clases trabajadoras (en el contexto de la afirmación de una "tercera vía"), que tanto el fascismo como el nacionalsocialismo, contemporizaron con el discurso procedente desde la izquierda apelando a las masas.

Pero, por otra parte, las distancias son claramente visibles no sólo en aspectos relativos al culto estatista o al racismo sino que se harían extensivas, tomando en cuenta, por supuesto, la fundamentación católica de la intelectualidad bajo análisis a otros, como a sus raíces ideológicas socialdarwinianas, o a la glorificación de la fuerza como

\footnotetext{
34 Rodolfo Martínez Espinosa, aludiendo directamente al estatismo mussoliniano, aclaraba en términos precisos su postura al respecto: "La fórmula "todo en el Estado, nada fuera del Estado...", indica, sin duda, una voluntad de potencia absoluta, pero si tal Estado ha dejado de ser agnóstico ha venido a concluir en autocrático, forma destinada a no menor fracaso que la anterior. El Estado, o mejor dicho, la Nación debe reconocer su condición de criatura contingente". SILLAU PEREZ Antonio, MARTINEZ ESPINOSA Rodolfo, Varios proyectos de preámbulos, Inédito, sin fecha. Por otra parte, como ya señalamos precedentemente, las ideas en torno al racismo biológico nacionalsocialista habían sido rechazadas en más de una oportunidad por los miembros del Instituto. Por ejemplo, Nimio de Anquín, lo había calificado de "herejía" y de "brutal" y, por lo tanto, "cae en las condenaciones de la Iglesia Católica"; Luís Martínez Villada, asumía una postura semejante, comentando los "excesos del mito de la sangre y del racismo", producto de la "secularización" o "descristianización" del mundo occidental. Nimio DE ANQUIN, Crisol, $1^{\circ}$ de febrero de 1939.
} 
valor de orden superior y a la violencia sistemáticamente organizada, o a las veleidades bélicas del puro expansionismo territorial o del predominio racial, o hacia el objetivo de la formación de un modelo de ciudadanía fascista o nacionalsocialista que priorizara en forma excluyente la militarización de la sociedad y la sumisión absoluta al Estado totalitario o a la raza como norma de todo.

También lo son, por ejemplo, el marcado elitismo que profesó esta intelectualidad, así como en "la ausencia del pragmatismo político que caracterizó a un Hitler o a un Mussolini, quedaba patentado en el carácter de "hecho espiritual", que Nimio de Anquín otorgaba al nacionalismo" 35 . Esto implicaba que la "revolución de los espíritus", preludio del advenimiento del "nuevo orden", constituía una acción esencialmente docente y a más largo plazo. Lo que no excluía cierta cuota de violencia (la "caridad violenta"), pero que carecía de fines políticos directos y operaba sobre esa "revolución espiritual". Esto no era óbice, por supuesto, para aceptar una "solución militar", si tomamos en cuenta su declarado abstencionismo político, para acelerar su "revolución espiritual"; pero esta "solución", en teoría, habría de provenir de manos exclusivamente ajenas.

En general, el recuento de todo este conjunto de rasgos, nos aproxima al reconocimiento que los elogios o la admiración que se pudieron profesar a la "obra" de Hitler o a Mussolini, se producían sobre un trasfondo radical y ortodoxamente católico, que señalaba, en nuestro caso específico, las rutas sobre las cuales se habría de fundar el "nuevo orden". En este sentido, las teorizaciones desplegadas pueden estar más cerca del modelo de Estado autoritario católico de un Oliveira Salazar o de un Dollfuss, o en lo que ya Nimio de Anquín había definido como "fascismo teocéntrico" (al aludir el levantamiento encabezado por Franco en España), que al modelo totalitario fascista o al estado völkish nacionalsocialista.

\section{Un nuevo escenario político y académico: 1936-1940}

Mientras tanto, en ese clima de turbulencias que agitaban a la sociedad argentina en sus más diversos planos, asumía la gobernación de Córdoba el "Dr. Amadeo Sabattini, hombre del partido radical, a quienes los nacionalistas no dudaron en denominar "gobernador bolchevique" habida cuenta su apoyo a la educación laica y a la labor de destacados pedagogos de la "Escuela Nueva" como Antonio Sobral, Saúl Taborda y Luz Vieira Méndez" ${ }^{\prime 36}$. Esto no tendría nada de particular si no fuera por el hecho de que en el país se asistía a un retroceso del "laicismo educativo desde los últimos años del gobierno

\footnotetext{
35 Nuestra fuerza no depende de ninguna contingencia carnal y, ciertamente, no somos nosotros quienes especulamos con el poder de las almas materiales...No somos los que soñamos con revoluciones, porque estamos convencidos que la verdadera revolución es la de los espíritus...(y) Podemos, con justicia, hablar de un nacionalismo cristianamente vivificado y nos arrogamos la posesión de sus principios...Aparte de la aceptación de las nociones en que se funda, exige el nacionalismo nuestro de quienes lo profesan una disposición biológica para el combate". DE ANQUIN, Nimio. (1936): Crisol, 12 de septiembre y 21 de noviembre. 36 Deodoro Roca consideraba a Sabattini como un "Vozarrón saludable que parece venir de la masa. Con hábitos de masa. Broncas y verdades. ROCA, Deodoro. (1956): El dificil tiempo nuevo. Buenos Aires. Lautaro. selección, prólogo y notas de Gregorio Bermann, p. 148.
} 
de Agustín Justo" ${ }^{37}$. El catolicismo de Córdoba no estaba dispuesto a perder espacios que consideraba claves y, por supuesto "naturales" y "legítimos"; y, en este sentido, "apelará" a la defensa de la patria y la "tradición" contra el "liberalismo exótico".

A su vez, la Universidad de Córdoba se aprestaba a elegir rector para el periodo 1936-1940. Los dos grupos opositores, reformistas y nacionalistas, trataron de conquistar posiciones aunque, desde la prensa y desde ciertos sectores independientes se advertía que en esa disputa no debía haber ni fascismo ni comunismo, sino solo democracia. De todos modos los enfrentamientos entre ambas facciones se producían a diario y por cualquier motivo ${ }^{38}$.

El 8 de noviembre, la asamblea universitaria reeligió al profesor de Derecho Civil, Dr. Sofanor Novillo Corvalán quien, en su primer discurso recordó que había tomado el mando de la institución en un momento de crisis aguda que procuró conjurar y consiguió con la combinación de dos elementos: un espíritu de concordia y una serena energía, afirmando que su política era justamente la de no hacer política y evitar que otros la hicieran. Y agregó " [...] no he terminado mi obra y si he puesto en ella cariño y esmero [...] Mi política será firme para lograr ese propósito, no lo seré menos para evitar que otros lo hagan" 39 . Las autoridades electas rebosaban de optimismo y pensaban que los conflictos político-ideológicos entre los dos sectores en pugna dentro de la casa habían concluido. Nada más errado, según veremos.

\section{La Conflictividad en la Universidad se Reanuda con una Huelga en 1938}

Para mediados de los años treinta los actores universitarios estaban bien definidos: los nacionalistas católicos por un lado y los reformistas por otro y ambos ejercerían constantemente presión y pujas para tratar de controlar los distintos estamentos. El 1 de junio, debían realizarse las elecciones para renovar las autoridades del Centro de estudiantes de Derecho, lo que lógicamente desató en los días previos una intensa acción de propaganda proselitista. Se presentaron tres listas denominadas "Unión Estudiantil Argentina, Democracia Estudiantil dirigida por Jorge Araya y Frente Reformista por Félix Martín. La primera que era de definición de derecha y nacionalista resultó victoriosa, siendo presidida por Heriberto Barrionuevo" ${ }^{40}$.

\footnotetext{
37 ZANATTA, Loris. (2002): Del Estado liberal a la nación católica, pp. 172-177 y 307315. VERA DE FLACHS, María Cristina. (2002): La educación primaria en el siglo XX, en ACADEMIA NACIONAL DE LA HISTORIA, Nueva Historia Argentina, tomo IX. Buenos Aires. Ed. Planeta, pp 397 - 424.

38 Por ejemplo, el 18 de octubre hubo un enfrentamiento entre los reformistas y un grupo de estudiantes que pertenecía a la Unión Nacional Fascista que apoyaba al ejército que partía de maniobras en la Estación del Ferrocarril Central Argentino. El hecho fue denunciado por los segundos al ministro del interior a quien le reclamaron que los "comunistas" gozaban de amplia libertad de propaganda y acción mientras ellos sufrían atropellos.

39 VERA de FLACHS, María Cristina. (2004): "Reformas y contrarreformas de la Universidad de Córdoba. 1870-1936", en Estudios sobre la Universidad latinoamericana. De la colonia al siglo XX. Madrid., Editorial Doce Calles, p. 183.

40 Los Principios dijo que la famosa reforma universitaria huía de los claustros provocándose el derrumbe de las células comunistas, a las que acusó de continuar agitando el ambiente al
} 
Esto no impidió que los reformistas de dicha Facultad se organizaran con el fin de preparar los actos con que conmemorarían los veinte años de la Reforma a la que pensaban invitar a otros compañeros de las restantes Facultades e individuos ajenos a la vida del instituto. Obviamente, el Centro de Estudiantes de Derecho se presentó ante el decano, Dr. Martínez Paz, para ponerlo en conocimiento de ese propósito y solicitarle adoptase medidas conducentes para impedir el acto en tanto suponían se provocarían situaciones de violencia. Era usual que, en esos años, los estudiantes produjeran luchas callejeras, pero éstas nunca pasaron de insultos o golpes de puño, pues ninguno de los grupos iba armado. Pero, en 1938, la temperatura subió y a diario había enfrentamientos que hacían prever un desenlace conflictivo. En previsión de posibles desórdenes se solicitó a la jefatura de policía el envío de una vigilancia especial en tanto el ambiente estaba caldeado. Los grupos nacionalistas aclamaban a la Patria, a la universidad católica y cantaban el Himno Nacional, mientras los antagonistas se agolpaban en la entrada de la Facultad de Ciencias Médicas prorrumpiendo exclamaciones adversas y gritando vivas a la Reforma y a la democracia.

El 13 de junio el rector, de acuerdo con el decano de la Facultad de Derecho, negó el permiso para realizar una manifestación dentro de los claustros con el objeto de desagraviar a la Nación y a otras instituciones. A pesar de la negativa los jóvenes reformistas arrojaron una profusión de volantes donde convocaban al acto prohibido lo que, a criterio de las autoridades de dicha Facultad, significaba desobediencia a lo dispuesto. "En consecuencia, el rector suspendió las actividades académicas por tres días e impidió la entrada de los estudiantes. Pero éstos no se dieron por vencidos y desde el frente del Hospital de Clínicas partió una columna que iría hasta el rectorado y de allí a la Plaza San Martín, donde escucharon la palabra de los señores Cabral, Quinteros y Arraya quienes pronunciaron discursos en contra del fascismo"41.

Por su parte, las agrupaciones nacionalistas aprovecharon la oportunidad para manifestarse en contra de la Reforma y entre otras cosas, la Corporación Argentina de Estudiantes Universitarios hizo pública la declaración que sigue:

La Reforma es intrínsecamente mala, negativa y destructora como resultado de la fermentación de intereses mezquinos y de pasiones desordenadas. La universidad no le debe ni luz en el orden de la inteligencia ni una doctrina moral. La democracia universitaria es tan mala como la democracia política, de la cual no es sino una prolongación dentro de la Universidad. El principio de jerarquía es fundamental en la vida universitaria: la confusión de todos en el límite mínimo es terriblemente injusta y absurda. La función propia del maestro es enseñar y la del alumno aprender, es evidente la existencia de una subordinación jerárquica. Proclamamos la necesidad de la restauración de los estudios sobre la base de la filosofia tradicional ${ }^{42}$.

punto que, para hacerse cargo del referido Centro, los jóvenes acudieron con un escribano quien labró el acta respectiva.

41 Los Principios. Córdoba. Argentina, 17 de junio de 1938, p. 7.

42 Los Principios, 17 de junio de 1938. 
Días más tarde, denunciaron que en el acto en conmemoración de la Reforma, que se celebró en el Teatro Rivera Indarte, los discursos habían sido de tinte demagógicoliberal marxista llegando a cantar el Himno Nacional con el puño cerrado y si bien reconocían que la Reforma había nacido como un justo deseo de reparar las graves fallas que adolecía la enseñanza y la organización docente, pronto cambió de ideales y perdió la ruta transformándose en bandera de desorden, apadrinando huelgas y protegiendo atropellos dentro y fuera de la Casa de Trejo. Y fueron aún más duros, al decir que la misma era un "movimiento de izquierda, instigado por el comunismo que con veladas propagandas y so pretexto de renovar valores hacía proselitismo tratando de adueñarse de la juventud a la que quería anular la personalidad frente al Estado".

El 11 de agosto se convocó a un plebiscito con el fin que los estudiantes ratificaran o rectificaran la posición adoptada por la Unión Estudiantil Argentina de separarse de la FUC. Los grupos antes mencionados se encontraron en la puerta del Decanato de Derecho. "La revuelta fue grande y sonaron tres tiros, cosa que no había ocurrido antes en la Universidad. Hubo una dispersión general y los nacionalistas tuvieron dos bajas. En el suelo quedó tendido Julio Benito de Santiago al tiempo que Francisco García Montaño, gravemente herido, falleció ocho días más tarde. Antenor Carreras Allende salvó su vida aunque quedó con serias secuelas físicas"43. De inmediato el decano de Derecho proveyó que se atendiera a los heridos, se suspendieran las actividades de los centros estudiantiles y que la policía tomara participación en los hechos señalando que el motín era fruto de la corriente de violencia que había invadido dichos grupos.

El hecho provocó una conmoción grande: dos muertos y un herido grave en la Universidad era demasiado. El rector convocó al C.S. para tratar el tema, ocasión en que los docentes volvieron a manifestar posiciones encontradas. El consiliario por medicina Dr. Guillermo Stuckert señaló que el Consejo estaba en mora con el dictado de la reglamentación de la constitución de los centros estudiantiles aunque, a su criterio, no debían disolverlos porque él tenía un hijo en uno de ellos y no creía que tuvieran ideas malsanas. La respuesta llegó a través de la palabra del decano de Ingeniería, Tezanos Pinto, quien le dijo que desconocía la realidad y que si leía la Gaceta Universitaria, órgano oficial de la Federación, vería como había extremismo en dichos centros y como: "desde ellos se vierten toxinas a los alumnos. Los centros están desvirtuados, añadió, y constituyen los canales por donde se introducía el extremismo en la Universidad" nuevamente en épocas "tranquilas, aclarando que los centros de estudiantes de ingeniería eran relativamente los más calmos de toda la Casa" ${ }^{45}$. En síntesis, se dispuso suspender

\footnotetext{
43 Alberto Novillo Saravia que acompañó en la ambulancia a Carreras Allende recuerda en una entrevista realizada por la Dra. Vera de Flachs que le preguntó quién lo había herido y que éste le respondió "el que me jodió fue Rufino Abaroa". Abaroa, estudiante de medicina, fue inculpado como sospechoso pero fue apoyado por la FUC y por la Liga por los Derechos del Hombre: Fue hábilmente defendido en la justicia, quien no pudo probar su culpabilidad por lo que fue absuelto y, en 1939-40, logró la presidencia de la FUC.

44 A.G.U.C, Actas de Sesiones del Consejo Superior. 1938.

45 A.G.U.C, Actas de Sesiones del Consejo Superior. 1938.
} 
las actividades docentes por una semana y toda actividad de los centros hasta que el C.S. dictara la reglamentación correspondiente designando a la Comisión de Vigilancia para que investigara lo ocurrido con el fin de reconocer los autores y aconsejando las medidas más convenientes.

Días después, el rector viajó a Buenos Aires con el fin de imponer al ministro de instrucción pública, Jorge E. Coll, de los acontecimientos ocurridos, a la vez que dio noticias de las actividades perturbadoras ocasionadas por los "elementos nazi-fascistas". Coll deploró los hechos no sólo por lo que significaban sino porque, a su criterio, era un rebajamiento de la cultura universitaria señalando la responsabilidad de los que estaban al frente de la Casa de Altos Estudios. Esta afirmación ocasionó un revuelo en Córdoba aseverando las autoridades universitarias que el episodio sangriento no tenía un carácter universitario sino que era una explosión de la violencia que estaba en los espíritus como fenómeno universal que asumía formas exasperadas en la juventud. Desdichadamente el mismo se había producido en la universidad y no era compatible con el progreso científico del instituto.

"Entretanto, el decano de Derecho sancionó a los que participaron, lo que ocasionó un roce con el rector quien opinó que era al C. S. el que debía tomar tal actitud, según lo disponía la ley Avellaneda" ${ }^{46}$. En su defensa, aquel argumentó que su actitud era preventiva para evitar actos que exaltaran más los ánimos y que ella tendría vigencia hasta que el C. S. dictase una ordenanza general. Su mesura no fue comprendida, a pesar del apoyo de los consejeros que señalaron que con esas disposiciones el decano no perseguía ningún fin sino que quería salvaguardar el orden en presencia de los actos que habían conmocionado a la opinión pública. Habían transcurrido veinte años de la Reforma y todavía había conflictos de poderes.

En definitiva, el tema le costó a Martínez Paz su renuncia como decano y como profesor titular de Filosofía Jurídica y de Derecho Civil Comparado y director del Instituto de Estudios Americanistas. Sin embargo, dado el prestigio académico del renunciante el rector junto a un grupo de colegas le solicitó considerara estas dos últimas dimisiones, consiguiendo que así lo hiciera.

\footnotetext{
46 La ley Avellaneda [ $\left.\mathrm{N}^{\circ} 1597 / 885\right]$, fue sancionada el 25 de junio de 1885 y delineó la organización universitaria nacional para los años subsiguientes, La misma autorizó a cada casa de altos estudios a darse su propio Estatuto La suerte de las mismas dependerían entonces de la responsabilidad en el actuar que demostraran sus claustros. Además dispuso que fuesen gobernadas por un rector, elegido cada cuatro años por la asamblea universitaria y por un Consejo Superior que conformaban el rector, los decanos de las Facultades y los delegados que éstas designasen. Si bien posibilitó que las Facultades redactaran sus propios reglamentos, reformaran sus planes de estudios y certificaran exámenes, sólo la Universidad era la encargada de otorgar los títulos o reválidas. La ley fue criticada desde el comienzo en tanto propició una fuerte dependencia con el poder ejecutivo nacional respecto a la selección del rector y de los profesores titulares quienes eran elegidos por éste de una terna que conformaba el Consejo Superior y cada Consejo Directivo de las respectivas Facultades toda vez que fuera necesario cubrir un cargo. VERA DE FLACHS, María Cristina. Reformas y Contrarreformas en la Universidad de Córdoba, de Sarmiento a Perón, Inédito.
} 


\section{La Lucha Estudiantil se Hace Extensiva al Cuerpo Docente}

Como acabamos de hacer notar los intelectuales y el claustro docente universitario se involucraría en estos conflictos y reproducían las posturas en pugna las que, a su vez, respondían ideológicamente a distintos sectores políticos. El caso más notable es el del profesor de Anquín quien, el 5 de noviembre de 1936, en un acto político de la Unión Nacional Fascista al que asistió una concurrencia numerosa, definió su concepto de nacionalismo proponiendo una fórmula que consistía en la primacía de lo moral sobre todo y en la desjerarquización de lo económico y lo político. "Un punto fundamental de su política era el carácter religioso del nacionalismo y la firme decisión de luchar contra el clima político liberal que imperaba en Córdoba en el gobierno del radical Amadeo Sabatini. Mientras De Anquín profería su discurso los asistentes al acto vitoreaban a la patria y al ejército y proferían gritos hostiles contra las autoridades de la Nación y de las provincias" ${ }^{\prime 7}$.

Los actos de la Unión Nacional Fascista se sucedieron ese mes, asignándoles un carácter especial, en tanto eran de afirmación nacionalista de la juventud y un repudio al comunismo. En el realizado a fines de septiembre no sólo hicieron uso de la palabra los representantes de diferentes sectores sociales de Córdoba, tal el caso del obrero Francisco Vargas que se refirió a la situación presente del proletariado y la solución justa del programa de la Unión Nacional Fascista, sino los que provenían de otras provincias o países y que se encontraban en esta ciudad, tal el caso de Herberto Pagani representante de la juventud santafecina que habló sobre La concepción de patria en el nacionalismo, liberalismo y comunismo, o el de un delegado de la falange española que había sido especialmente invitado para hacer uso de la palabra y recibir el apoyo de los fascistas argentinos habida cuenta la lucha que llevaba su grupo por imponer el resurgimiento de la "hispanidad auténtica"48. En cualquier caso, se ponía de manifiesto la preocupación central por lo que denominaban la acción destructora del comunismo en los pueblos cristianos.Recordemos que, por ese tiempo, tanto De Anquín como otros miembros de la Unión Nacional Fascista, intentaban realizar una intensa tarea de captación de la juventud, particularmente entre los estudiantes universitarios y del Colegio Monserrat. El 21 de noviembre De Anquín habló en el teatro Coliseo de Buenos Aires ante una sala desbordada de jóvenes donde señaló para las nuevas generaciones argentinas la urgencia del restablecimiento de una verdadera actitud cristiana. Dijo entonces:

[...] para nosotros el cristianismo en un hecho tan tangible como el que más real como el que más y lo aceptamos así integralmente... Aquí están las

\footnotetext{
47 A su fin se produjeron incidentes y en consecuencia fueron detenidos algunos de los participantes del acto entre ellos Jorge A. Castro, Antenor Carreras (h), Gustavo Vernet (h), Arturo Vitelli, Carlos Viale, Luis Peñeñory y Antonio Cordero.

48 Las luchas ideológicas se irradiaron a distintas provincias y con diversas consecuencias, por ejemplo en Mendoza el gobierno por decreto separó de su cargo al profesor de la Escuela Superior de Comercio, Rafael Dervezo Morales, quien se desempeñaba además como director de la Universidad Popular por ser "un activo propagandista de ideologías disolventes y antisociales".
} 
raices de nuestro nacionalismo que aunque a veces se refiere a la ciudad terrestre y vive en el orden de lo político temporal también posee una zona de interferencias en que sus principios reciben de la ciudad celeste, que proyecta su sombra sobre el mundo que participa ${ }^{49}$.

Poco después, el Dr. Martínez Villada se opuso en el Consejo Superior que se hiciera un homenaje a Juan Bautista Alberdi y se difamara la memoria de Juan Manuel de Rosas. Hubo un gran escándalo habida cuenta que varios ex alumnos salieron a defender al maestro, entre ellos Nimio de Anquín, quien fue suspendido en sus cátedras del Colegio Monserrat. Manuel Río que compartía sus ideales, renunció a las suyas por solidaridad. También lo hicieron otros docentes entre los que se contaban Rogelio Nores Martínez, Manuel Augusto Ferrer, Raúl Pucheta Morcillo y algunos estudiantes que militaban en la agrupación Unión de Fuerzas Fascistas, entre los que se destacaban Raúl Mendé, Erio Bonetto, Carlos G. Berardo, Alberto Díaz Bialet y Carlos José Caballero ${ }^{50}$.

\section{La expulsión de un nacionalista y su destierro}

Cuando el país se preparaba para la sucesión presidencial de 1938 los diferentes grupos nacionalistas se sintieron desalojados de la escena política y se lanzaron a la calle en una decidida acción de intimidaciones y con un programa a desarrollar que consistía en:

1. Toma de la dirección espiritual del poder para imponer un cambio de estructuras políticas y sociales bajo el lema Dios, Patria y Familia.

2. Conquista de la Universidad y reforma educacional aplicando la enseñanza religiosa.

\section{Captación sindical.}

\section{Restricciones a la libertad de prensa y pensamiento ${ }^{51}$.}

Esta acción directa ejecutada por los nacionalistas estaba destinada a reprimir las ideas liberales y las de la izquierda. La crisis de los partidos políticos tradicionales actuó como caldo de cultivo para que estas organizaciones se desarrollaran y lograran la adhesión de los jóvenes. Los intelectuales del Instituto Santo Tomás de Aquino también adhirieron a la difusión de estos puntos básicos. Esto explica la exposición de Anquín, el 11 de agosto de 1939, cuando en un acto político pronunció un nuevo "discurso que contenía expresiones agraviantes contra la nación, sus instituciones y países que tenían

\footnotetext{
49 Texto publicado en Crisol, 22 de noviembre de 1936.

50 Varios de los nombrados años más tarde militaron en las filas del peronismo y detentaron cargos políticos y académicos. Nores Martínez fue rector de la Universidad, Caballero gobernador de Córdoba, Bonetto diputado provincial, Mendé Secretario legal y técnico de la presidencia de la Nación durante el primer gobierno de Perón y Berardo Ministro de Hacienda durante el gobierno de Felipe Luchini.

51 Ibídem. p. 45
}

Rhela. Vol. 12. Año 2009, pp. 247 - 273 
estrecha relación con ésta añadiendo, en su parte final, una incitación a la rebelión contra ellas, lo que provocó de inmediato un movimiento de repudio proveniente de diversos sectores de la sociedad" ${ }^{2}$.

Las reacciones en el seno de la comunidad universitaria no tardaron en aparecer. Teniendo en cuenta que se trataba de un docente que había sufrido diversas sanciones por causas análogas tiempo atrás, el rector dispuso suspenderlo y citarlo al C. S. para que diera las explicaciones del caso. Ante su negativa a asistir se enviaron los antecedentes a una comisión integrada por los Drs. Guillermo Stuckert y Jorge Nuñez y el ingeniero Julio Tezanos Pinto, quienes aconsejaron su destitución por considerar que si bien esas expresiones habían sido realizadas en un acto político, De Anquín era reincidente en ese tipo de manifestaciones dentro y fuera de la cátedra donde hacía propaganda constante en contra de las instituciones y difamando figuras de próceres, como Alberdi y Sarmiento, e inculcando a los jóvenes a que tuviesen aversión a ellos y sus obras. Pero lo más preocupante era que con sus actitudes y predicamento, había logrado moldear a un grupo de jóvenes universitarios y estudiantes monserratenses, lo que alarmaba al sector reformista que veía con desagrado su figura.

En efecto, la llegada de Anquin a los jóvenes era importante, al punto que éstos junto a un grupo de profesores de la Universidad y del Colegio, jugaron una fuerte carta en su defensa enviando una nota al rector donde señalaban que los conceptos vertidos no constituían una falta grave contra el orden social, por lo que peticionaban dejara sin efecto la medida. Pero éste consideró que los motivos que fundaban la petición constituían una falta de respeto a su autoridad además de contener términos que molestaron al claustro, tales como "cuadrúpedos democráticos y que se estaba perjudicando a la niñez con el mito democrático". "En consecuencia, sancionó a los alumnos y docentes que habían firmado la misiva de solidaridad con el cesanteado" ${ }_{53}$.

52 La Voz del Interior criticó duramente la posición adoptada por el docente en varios artículos aparecidos esos días. Lo calificó como "el profesor imposible" incorporado a las instituciones educativas sólo por las combinaciones que caracterizaban las políticas de acomodo dentro de la universidad, acusándolo de ser un filósofo nacionalista a lo tomista, a lo nazi, que despotricaba contra la constitución nacional, razón por la que impulsaba a reclamar al Consejo Superior la aplicación de sanciones ejemplares. Mientras, Los Principios, adoptaba una posición contraria y publicaba notas de adhesión a De Anquín firmadas, entre otros, por el presbítero Octavio N. Derisi y los católicos Manuel Villada Achával, Fernando García Montaño, Juan Carlos Moreno, Ascencio Viramonte Oliva y Desiderio Villahoz,

53 Entre los docentes se contaban los Drs. León S. Morra, Clemente Villada Achával, Lisardo Novillo Saravia, Luís Villada Achával, Ramón A. Brandán, Carlos G. Carranza, Benjamín Galíndez, José Cortés Funes, Enrique Ferreira, el ing. Rogelio Nores Martínez, el arq. Miguel Arrambide, Jerónimo González, Conrado, Juan B. y Manuel Augusto Ferrer, los adscriptos Rafael Moyano Crespo, José Inaudi y Lisardo Novillo Saravia [h.]; el Jefe de Trabajos Prácticos Dr. Raúl Pucheta Morcillo y el celador del Monserrat anexo Pedro Edmundo Oviedo. Los alumnos que firmaron la nota fueron: Raúl A. Mende, Juan Rodríguez Leonardi, Eduardo Fantini, Ambrosio A. Díaz, Américo Luis Viotti, José V. Sapeño, Juan C. Reyna, Miguel García Montaño, Roberto Rigo, Antenor Carreras Allende, Guillermo Martínez Díaz, Jorge Martínez Casas, Alberto Gordillo, Ignacio Sársfield, Virgilio Gómez Dávila, Enrique Garcero, Juan Valinotto, R. Domicelli Álvarez, Francisco García, Pedro J. Frías h., Jorge Castro, Jorge Usandivaras, Erio Bonetto, 
Días después "el Dr. Martínez Villada solicitó se lo incluyera entre los castigados porque él también adhería a favor de De Anquín" 54 .

A comienzos de septiembre cuando parecía que el tema se había acallado, el mismo De Anquín lo puso de nuevo en el tapete al dirigir una extensa nota al Consejo Superior pidiendo reconsideración de la medida e invalidando jurídicamente las razones invocadas para destituirlo de sus cátedras en el "Monserrat, que poseía por concurso desde hacía ocho años y en las cuales había puesto todo su esfuerzo para modernizar la enseñanza, reformulando sus programas e introduciendo bibliografía nueva" 55 .

En verdad, nadie negaba sus conocimientos y estudios realizados en Hamburgo con Ernesto Cassirer, Alberto Goerland y N. Sauer, gracias a la beca otorgada por la universidad de Córdoba. Eso no estaba en discusión, el tema principal pasaba por otro lado. El tenor de la nota presentada era muy fuerte y atacaba la resolución en todos sus aspectos rebatiendo los argumentos esgrimidos en su contra y tratando de demostrar, en primer término, que no era un agitador peligroso que estaba en pugna con las instituciones republicanas y luego, que el nacionalismo argentino no era una doctrina anárquica y que la democracia liberal estaba formalmente condenada por la Iglesia.

Al finalizar el texto hacía una defensa vigorosa de su vida privada y pública sosteniendo que la resolución rectoral fue inspirada en la pasión y resentimientos personales más que por la razón, haciendo presente que tanto el rector como los consiliarios Doctores Carlos R. Melo, Jorge Núñez y Guillermo Stuckert y el ing. Julio Tezanos Pinto no se habían excusado de actuar aun cuando era evidente que mantenían una enemistad personal con él. Con respecto a este último dijo, además, que le extrañaba sus acusaciones pues pocos días antes había pronunciado un discurso en el Monserrat donde hizo referencia a un tema similar a los por él expuestos, cuando hablando de la deformación de la "argentinidad" señaló que la extranjerización que venía soportando el país era fuerte.

De igual manera pensaba que el rector tenía coincidencia con su pensamiento habida cuenta que el 11 de abril de ese año, en un discurso marcó la crisis de las instituciones democráticas usando el término de "deidad equívoca", que era lo mismo que él denominaba "Dios abstracto". Finalmente acusó al decano de Medicina Dr. Stuckert y al Dr. Carlos Melo de radicales militantes que habían anticipado su juicio en contra, además de estar implicado el primero en "la tragedia de Plaza Mercedes" ${ }^{5}$. A

\footnotetext{
Manuel E. Ferreyra, R. y L. Arrigoni Blanco, Rafael Buteler, Domingo, Gustavo y Horacio Funes Gueselaga, Guido Soaje, H. Muñoz, Delfin Maldonado, Rodolfo Aliaga, Silvio Antonio Tosello, Horacio Malchiona y José R. Olivos. A.G.U.C., Decretos Rectorales, 1939, fs 258 a 265. Ver además La Voz del Interior, 15, 19, 22 y 23 de agosto de 1939.

54 A.G.U.C., Decretos Rectorales, fs. 265.

$55 \mathrm{Al}$ respecto recordó que hasta su llegada a la institución la enseñanza de la filosofía se limitaba a repetir de memoria la octava edición del manual de Lahr, cuando en Francia iban por la 24 edición mejoradas.

56 Plaza Mercedes era un pequeño poblado que vivió un hecho inusitado durante las elecciones provinciales de 1935 que enfrentó al partido demócrata y radical. En su plaza central se produjo un tiroteo entre los dirigentes de ambas facciones y como corolario, en breves momentos, resultaron once policías y dos radicales muertos, lo que causó hondo pesar en la provincia.
} 
pesar de tan extensa defensa, el C. S. mantuvo su posición argumentando que se lo había amonestado en otras oportunidades y se le había prevenido que en caso de reincidir en el tema, se lo separaría del cargo. Luego el rector designó en reemplazo de Anquin para sus cátedras en el Monserrat a los Dres. Alfredo Fragueiro y Alfredo Poviña. "El cesanteado se exilió un tiempo fuera de la provincia" ${ }^{57}$. Con este hecho se decretó la muerte del Instituto Santo Tomás de Aquino cuyos miembros se dispersaron

\section{CONCLUSIONES}

Una dura editorial periodística aparecida en agosto de 1939 señalaba que los campos de batalla en el país donde por largo tiempo habían luchado indios, gauchos y caudillos, habían cambiado de escenario en el siglo XX, ahora las luchas fratricidas se llevaban a cabo en escuelas, colegios y universidades y agregaba:

La comandancia se llama cátedra y el caudillo ladino, grosero y traidor catedrático... Se llaman nacionalistas, fascistas vergonzantes como lo es la sutileza vil de su traición en ejercicio de la docencia... La Universidad de acuerdo con la "curia fascista" ha llenado nuestras instituciones de esta suerte de catedráticos que parecen los avanzados del ejército ${ }^{58}$.

En verdad, el conflicto con De Anquín adquirió proporciones insospechadas y puso al descubierto que en la Universidad de Córdoba los enfrentamientos entre reformistas y nacionalistas eran intensos y que los asuntos universitarios eran conducidos con la misma pasión que los conflictos políticos.

El estallido de la segunda guerra mundial complicó aún más el panorama habida cuenta que la Nación se vería afectada por el rumbo que tomaban los acontecimientos. Los nacionalistas que, sin dudas, mostraban simpatías por el viraje autoritario de la Europa de entreguerras creyeron que había llegado su hora. Innumerables citas podríamos hacer sobre las manifestaciones que se publicaban en la prensa reconociendo el talento de un Mussolini, un Franco y hasta un Hitler pese a la declarada neutralidad que proclamaba el país que, por lo demás, era la mantenida diplomática e

\footnotetext{
57 A.G.U.C., Actas del Consejo Superior, agosto y septiembre de 1938. Los Principios defendió a De Anquin sosteniendo que si se lo reincorporaba a sus cátedras no solo se podía reparar el daño sufrido por el docente sino que la materia que estaba en sus manos volvería a contar con una persona proba. Durante varios días destinó varias columnas para publicar la nota de De Anquín completa. Días más tarde, los profesores Carlos Brandán Caraffa y O. Ferrer y los alumnos Juan Carlos Reyna, Santos M. Raspanti y F. Arrigoni Blanco que, en un primer momento, habían sido sancionados reclamaron al rector expresando que ellos no habían firmado la nota ni habían autorizado a nadie a que lo hicieran en su nombre, lo que fue considerado favorablemente. Igual actitud tomó Lisardo Novillo Saravia quien cursó una nota al rector a raíz del apercibimiento que se le impuso con este motivo, solicitando se dejara sin efecto la medida, en tanto su vida era modesta y sus actitudes no pasaron más allá de la cátedra, aunque señalando que en todos los órdenes mantuvo una unidad de pensamiento y acción.

${ }^{58} \mathrm{La} \mathrm{Voz} \mathrm{del} \mathrm{Interior,} \mathrm{"Los} \mathrm{nacionalistas} \mathrm{en} \mathrm{la} \mathrm{docencia",} 24$ de agosto de 1939", p. 6, col. 1. La cursiva es nuestra.
} 
institucionalmente por El Vaticano y por la Iglesia argentina. Sin duda, las ambigüedades mostradas frente al caso italiano o alemán y su utilización instrumental, permitían arribar a definiciones tales como la de un "totalitarismo cristiano.

Luís Martínez Villada, intelectual que sintetizaba el proyecto que animaba a los miembros del Instituto Santo Tomás, en tal definición, de fundar ese "nuevo orden" nacional, fundaba el mismo en la confesionalidad católica integral, donde "todo el orden cósmico y de modo especial el humano, es un orden teocrático. En el Estado cristiano se alcanza, pues, la plenitud el carácter de totalitario, porque en él el hombre es dirigido por las dos espadas hacia la plenitud de sus fines: "No es pues en la naturaleza totalitaria del Estado, no en la severidad de su disciplina, donde hay que buscar los principios de desviación, sino en la concepción de sus fines" ${ }^{\prime 2}$; es decir, como señalamos up supra, las expresiones de admiración o calificación favorables a tales regímenes se producían sobre un trasfondo radical y ortodoxamente católico. Los reformistas, por su parte, se proclamaron neutralistas repudiando la guerra al igual que la Convención Nacional de Centros de Estudiantes, reunida en octubre de 1939 y ello se explica por la existencia del pacto Molotov-Ribbentrop. En ese momento el partido comunista argentino dio la orden de no atacar a Hitler, "amigo de Stalin", posición que se revierte en 1941 cuando se produjo la invasión nazi a la Unión Soviética.

Mientras, la actitud asumida por la intelectualidad independiente, los socialistas y los sectores liberales del partido radical y del demócrata fue, desde el principio, muy distinta ya que condenaron abiertamente al III Reich y al fascismo. En concreto, hasta finalizar el período de estudio la puja ideológica política estuvo presente en la universidad y en el Monserrat, lo que explica que el movimiento estudiantil y el claustro docente mantuvieran un alto grado de politización y las mismas prácticas.

Varios hechos demuestran este aserto, pero dada las limitaciones de espacio sólo mencionamos que, en mayo de 1940, los Centros de Estudiantes solicitaron levantar la interdicción que pesaba sobre ellos por los hechos ocurrido el 11 de agosto de 1938, lo que fue aprobado por unanimidad de votos en el C. S. "Poco después se convocó a la realización del Tercer Congreso de Estudiantes a celebrarse en Córdoba del 2 al 5 de octubre de 1942, evento que concitó la presencia de 36 centros de las cinco federaciones existentes en el país y el que tuvo un marcado tinte antifascista" ${ }^{60}$. El golpe militar del 4 de junio de 1943 abriría nuevas esperanzas para los nacionalistas, sin embargo no tardaron en comprobar que sus expectativas no iban a efectivizarse en tanto el régimen de "nueva cristiandad" o el "totalitarismo cristiano" no llegaría a cristalizar, pero de cualquier modo, la "vieja Argentina" y su legado histórico ochentista tocaba su conclusión.

\footnotetext{
59 MARTÍNEZ VILLADA, Luís Guillermo. (1939): "El Estado totalitario", en Arx, No 3, Córdoba, pp. 216-217.

${ }^{60}$ AGUC., Actas del Consejo Superior, 1940, Tomo único.
} 


\section{FUENTES}

\section{FUENTES PRIMARIAS}

Carta a Julio Irazusta, noviembre de 1936, Inédita. Cedida por Dr. Alberto Caturelli.

MARTÍNEZ ESPINOSA Rodolfo, Varios proyectos de preámbulos, Inédito, sin fecha.

\section{ARCHIVO}

Archivo General de la Universidad de Córdoba

Decretos Rectorales, 1939. 1940

Actas del Consejo Superior, 1938 y 1940.

\section{Periódicos y Revistas}

Arx $N^{\circ}$ 3, Córdoba 1939

Crisol 1938

La Nación 1930-1943

La Voz del Interior 1930.1943

Los Principios 1930-1943

\section{SELECCIÓN BIBLIOGRÁFICA}

BUCHRUCKER, Cristián. (1987): Nacionalismo y peronismo. La Argentina en la crisis ideológica mundial (1927-1955). Buenos Aires. Editorial Sudamericana.

CATURELLI, Alberto. (1993): Historia de la Filosofía en Córdoba El siglo XX, Córdoba.

DE ANQUIN, Nimio. (1941): "Liberalismo subrepticio y libertad cristiana", en Nueva Política, $\mathrm{N}^{\mathrm{o}} 10$, Buenos Aires.

DE BLAS GUERRERO, Andrés. (1984): Nacionalismo e ideologías políticas contemporáneas. Madrid. Espasa Calpe.

(1989): Sobre el nacionalismo Español, CEC. Madrid.

DEVOTO, Fernando. (2002): Nacionalismo, fascismo y tradicionalismo en la Argentina moderna. Una historia, Siglo XXI. Buenos Aires.

MALLIMACI, Federico. (1998): El catolicismo integral en la Argentina (1930-1946), BiblosFundación Simón Rodríguez. Buenos Aires.

Mc DEUTSCH, Sandra. (2005): Las derechas. La extrema derecha en la Argentina, el Brasil y Chile, Editorial de la Universidad Nacional de Quilmes.

MARTÍNEZ VILLADA, Luís Guillermo. (1939): "El Estado totalitario", en Arx, N 3 , Córdoba. 
. (1939): Democracia y orden político, Córdoba.

NOLTE, Ernst. (1964): Three faces of fascism: Action Française, Italian fascism, nationalsocialism. New York. New American Library.

ORDORIKA, Imanol. (2006): La disputa por el campus, poder, política y autonomía en la UNAM. México. UNAM.

PAYNE, Stanley. (1982): El fascismo. Madrid. Editorial Alianza.

ROCK, David. (1993): La argentina autoritaria. Los nacionalistas su historia y su influencia en la vida pública. Buenos Aires. Editorial Ariel.

SILLAU PEREZ, Antonio. (2008): Caracterización del pensamiento nacionalista en Córdoba en el período de entreguerras. Una propuesta católica desde el interior (1919-1943), España Universidad Internacional de Andalucía. Tesis de Maestría, inédita.

TREVOR ROPER, Hughes. (1968): The phenomenon of fascism, en Wolff S (ed), European Fascism, Weindenfeld and Nicholson, Londrés.

VERA DEFLACHS, María Cristina. (2005): "Reformas y Contrarreformas en la Universidad de Córdoba, 1918-1936", en VARGAS HERNANDEZ, Olmedo. ed., Movimientos Universitarios. América Latina siglo XX. Colombia. Editorial Jotamar.

(2002): La educación primaria en el siglo XX, en Academia Nacional de la Historia, Nueva Historia Argentina, tomo IX, Buenos Aires, Ed. Planeta.

. (2004): Reformas y contrarreformas de la Universidad de Córdoba. 18701936", en Estudios sobre la Universidad latinoamericana. De la colonia al siglo XXI. Madrid. Editorial Doce Calles.

ZANATTA, Loris. (1996): Del estado liberal a la nación católica. Iglesia y ejército en los orígenes del peronismo. 1930-1943, Quilmes, Universidad Nacional de Quilmes.

ZULETAÁLVAREZ, Enrique. (1975): Introducción a Maurras., Nuevo Orden, Buenos Aires, 1965. Buenos Aires. Editorial La Bastilla.

España y el nacionalismo argentino, en Cuadernos del Sur, No 23-24.

Los gobiernos de la Concordancia, en Academia Nacional de la Historia, Nueva Historia de la Nación Argentina., vol. VII.

VERA DE FLACHS, María Cristina y SILLAU PÉREZ, Antonio. (2009): "Ideología y Política Docentes y Estudiantes en el Contexto De La Crisis Liberal Argentina El caso de la Universidad de Córdoba (1930-1943))", en Revista Historia de la Educación Latinoamericana No 12, Tunja, Universidad Pedagógica y Tecnológica de Colombia, RUDECOLOMBIA, pp. $247-273$. 